\title{
Abnormalities in Enamel Structure and Their Association with Systemic Diseases and Syndromes
}

\author{
Marko Jeremić1, Dejan Marković ${ }^{2}$, Ana Vuković2 ${ }^{2}$ Marko Babić 3 , Vukoman Jokanović ${ }^{4}$ \\ 'Health Center, Jagodina, Serbia; \\ 2Department of Pediatric and Preventive Dentistry, School of Dentistry, University of Belgrade, Belgrade, Serbia; \\ 3 Institute of Biology and Human Genetics, School of Dentistry, University of Belgrade, Belgrade, Serbia; \\ ${ }_{4}^{4}$ Institute for Nuclear Research Vinča, Belgrade, Serbia
}

\begin{abstract}
SUMMARY
Etiology of abnormalities in tooth structure has been subject of numerous studies but still has not been fully understood. Heredity is an established etiological factor for many types of structural anomalies of the teeth. Factors that cause changes in enamel structure may be genetic, immunologic and teratogenic or systemic diseases. Genetic changes may include individual genes, micro deletions or chromosomal defects. Systemic diseases can be associated with anomalies of tooth structure and diversity of clinical picture requires a multidisciplinary approach to the therapy. Amelogenesis imperfecta (AI) represents a large group of structural abnormalities of the teeth. Al can exist independently or as a part of large number of syndromes and systemic diseases. Knowledge of clinical presentation, etiology, pathogenesis of structural anomalies of the teeth and their association with certain systemic diseases is of great importance to everyday dental practice in terms of prevention, prognosis and therapy. Also, it is necessary to expand basic knowledge of pediatricians in regards to the clinical picture of anomalies in tooth structure and their possible association with a wide range of systemic diseases and syndromes, in order to provide comprehensive clinical treatment. Therefore, the aim of this study was to present etiopathogenesis and classification and to describe the most important abnormalities of enamel structure and their association with systemic diseases and syndromes.
\end{abstract}

Keywords: abnormalities of tooth structure; amelogenesis imperfecta; enamel hypoplasia; heredity; syndrome; systemic diseases

\section{INTRODUCTION}

Structural abnormalities of enamel represent a wide group of disorders that include alterations during enamel formation due to genetic or environmental factors. The first and earliest evidence of these anomalies dates back to 1.5 million years ago. General enamel hypoplasia of teeth, reduced transparency and attrition has been found on skeleton remnants of Homo erectus-child from Ethiopia. The oldest written records of vertically grooved enamel are dating from year 1100 and have described the teeth in remains of a North American Indian child [1]. Modern research has described different frequency of enamel abnormalities in investigated areas in the world. The lowest frequency has been recorded in a survey conducted in US population 1:14,000 [1]. Study conducted by Chosak et al. [2] in Israel has recorded the incidence of 1:8,000 for abnormalities of tooth structure in the population. Epidemiological studies conducted in Western European countries have shown a higher incidence of these abnormalities as compared to the data obtained from American studies. The determined incidence in Sweden has been 1:4,000 [3], while a survey of Vesterboten area in Sweden has recorded the incidence of 1:700 [4]. Based on the study of Džolev et al. [5], the prevalence of tooth anomalies in
Serbia in 1980 was 1:12,582. Additional comprehensive epidemiological studies are needed to update the information about the incidence and prevalence of structural anomalies of the teeth in the population of children and adolescents in Serbia.

Socio-economic and clinical significance of Amelogenesis imperfecta (AI) and other structural anomalies of the teeth reflects as life quality alteration of patients and their families. Therefore, good knowledge of possible etiological factors, timely diagnosis, individual and multi-disciplinary approach to the treatment procedures is important for comprehensive and adequate treatment of these patients.

The aim of this study was to present the etiopathogenesis and classification as well as to describe the basic abnormalities of enamel structure and their association with systemic diseases and syndromes.

\section{ETIOPATHOGENESIS OF ABNORMALITIES OF ENAMEL STRUCTURE}

Tooth development includes a period from formation and migration of neural crest cells around day 22 during intrauterine embryogenesis up to the completion of growth 
and root development of third molars or wisdom teeth at about $20-25$ years of age. Odontogenesis is a complex process of tooth formation and it goes through several stages: the initial formation of dental lamina, bud stage, cap stage, bell stage, root formation and final differentiation of odontoblasts and ameloblasts, postmytotic cells that produce dentin and enamel. Modern research has shown that odontogenesis is under special control of more than 300 genes [6]. Tooth abnormalities have been described as a part of many clinical syndromes. London database of genetic information (LGD) have been depicted 447 syndromes and diseases associated with dental anomalies [7].

Enamel matrix formation is controled by matrix proteins and enzimes-proteinases, as well as by transcription factors involved in gene expression which control the synthesis of matrix proteins and proteinases. Synthesis of enamel matrix proteins, most notably Enamelin and Amelogenin, is controlled by multiple genes and enzymes of which the most important are Kalikrein and Metal Matrix proteinase 20 (MMP-20) [8]. Abnormalities of enamel structure during the process of its formation are caused by deficiencies in the function of protein enzymes as the consequence of their genetic alterations [9].

Etiology of structural anomalies of the teeth is the subject of numerous studies and has not been yet fully clarified. A large number of different clinical disorders of enamel structure have been indicated as consequences of different diseases and syndromes that have caused alterations of dental structure. Modern research has shown that many types of AI result from genetic deficiencies, either independently or as a part of different syndromes [10].

\section{CLASSIFICATION OF ABNORMALITIES OF ENAMEL STRUCTURE}

Based on results of modern investigations it has been found that various clinical manifestations of structural anomalies of the teeth are consequences of specific gene abnormalities related to the mode of inheritance [11]. Classification has been performed based on clinical presentation, type of inheritance, and specific genes mutations determined by genetic examination of the affected person and close family members. There are number of classifications and divisions available in the literature, which may be explained by heterogeneous characteristics of the disease.

$\mathrm{AI}$ is often described as an isolated anomaly of enamel structure [12]. Mild clinical form implies a slight crown discoloration. Severe clinical form of the disease is characterised with poorly mineralized or missing enamel in both dentitions and attrition that occurs soon after eruption. Basically, an anomaly of enamel structure may occur as the result of insufficient enamel production, poor mineralization, irregularities present in the organic matrix or due to the combination of these factors [13].

The first classification of AI given by Weinmann et al. on hypoplastic and hypocalcification type is dating from 1945 [11]. Witkop's classification, which includes four large groups and its subsequent revision to fourteen subtypes based on the mode of inheritance, radiological and histological appearance is currently the most commonly used classification (Table 1). Witkop's type of AI or enamel agenesis is described as a separate line of AI where enamel formation is seriously disrupted or enamel is not formed at all.

Table 1. Classification of Amelogenesis imperfecta according to Witkop [10]

Tabela 1. Klasifikacija amelogenesis imperfecta prema Vitkopu [10]

\begin{tabular}{|c|c|c|c|c|}
\hline $\begin{array}{l}\text { Group } \\
\text { Grupa }\end{array}$ & $\begin{array}{l}\text { Incidence } \\
\text { Učestalost }\end{array}$ & $\begin{array}{l}\text { Subtype } \\
\text { Podtip }\end{array}$ & $\begin{array}{l}\text { Inheritans } \\
\text { Nasleđe }\end{array}$ & $\begin{array}{l}\text { Clinical picture } \\
\text { Klinička slika }\end{array}$ \\
\hline \multirow{7}{*}{$\begin{array}{l}\text { Hypoplastic type } \\
\text { Hipoplastični tip }\end{array}$} & \multirow{7}{*}{$60-73 \%$} & 1 & Ad & $\begin{array}{l}\text { Hypoplastic fossas } \\
\text { Hipoplastične jamice }\end{array}$ \\
\hline & & 2 & Ad & $\begin{array}{l}\text { Local hypoplasic changes } \\
\text { Lokalne hipoplastične promene }\end{array}$ \\
\hline & & 3 & $\mathrm{Ar}$ & $\begin{array}{l}\text { Local hypoplasic changes } \\
\text { Lokalne hipoplastične promene }\end{array}$ \\
\hline & & 4 & Ad & $\begin{array}{l}\text { Smooth hypoplasic changes } \\
\text { Glatke hipoplastične promene }\end{array}$ \\
\hline & & 5 & Ad & $\begin{array}{l}\text { Smooth hypoplasic changes } \\
\text { Glatke hipoplastične promene }\end{array}$ \\
\hline & & 6 & $\mathrm{Ad}$ & $\begin{array}{l}\text { Rough hypoplasic changes } \\
\text { Hrapave hipoplastične promene }\end{array}$ \\
\hline & & 7 & Ad & $\begin{array}{l}\text { Rough hypoplasic changes } \\
\text { Hrapave hipoplastične promene }\end{array}$ \\
\hline \multirow[b]{3}{*}{$\begin{array}{l}\text { Hypomaturation type } \\
\text { Hipomaturacioni tip }\end{array}$} & \multirow[b]{3}{*}{$20-40 \%$} & 1 & $\mathrm{Ar}$ & \multirow{3}{*}{$\begin{array}{l}\text { Enamel of normal thickness; mineralisation disturbances; color of } \\
\text { deciduous teeth - opaque white; color of permanent teeth - chalky } \\
\text { white, yellow to brown-striped enamel } \\
\text { Gleđ normalne debljine; poremećaj mineralizacije; boja mlečnih zuba } \\
\text { - opaker bela; boja stalnih zuba - od kredasto-bele, žute do smeđe - } \\
\text { tigrasta gleđ }\end{array}$} \\
\hline & & 2 & $X$ & \\
\hline & & 3 & Ad & \\
\hline \multirow[b]{2}{*}{$\begin{array}{l}\text { Hypocalcification type } \\
\text { Hipokalcifikovani tip }\end{array}$} & \multirow[b]{2}{*}{$7 \%$} & 1 & $\mathrm{Ad}$ & \multirow{2}{*}{$\begin{array}{l}\text { Enamel less mineralised; milky white, brown or dark color; normal thick- } \\
\text { ness of enamel at eruption, removed after } \\
\text { Gleđ nedovoljno mineralizovana; mlečno bele, svetlosmeđe ili tamne } \\
\text { boje; normalna količina gleđi pri nicanju, ljušti se po nicanju }\end{array}$} \\
\hline & & 2 & $\mathrm{Ar}$ & \\
\hline \multirow{2}{*}{$\begin{array}{l}\text { Hypoplastic-hypomaturation } \\
\text { type with taurodontism } \\
\text { Hipoplastično-hipomaturacioni } \\
\text { tip sa taurodontizmom }\end{array}$} & \multirow[b]{2}{*}{$3-11 \%$} & 1 & $\mathrm{Ad}$ & \multirow{2}{*}{$\begin{array}{l}\text { Great areas of hypomineralization; dentin with lower number of tubules; } \\
\text { greater amount of intertubular dentin; pulp chamber increased } \\
\text { Široka polja hipomineralizacije; dentin s manjim brojem kanalića; } \\
\text { veća količina intertubularnog dentina; uvećana pulpa }\end{array}$} \\
\hline & & 2 & $\mathrm{Ar}$ & \\
\hline
\end{tabular}

Ad - autosomal dominant; $\mathrm{Ar}$ - autosomal recessive; $\mathrm{X}$ - inheritance by $\mathrm{X}$-chromosom

$A d$ - autozomno dominantno; $\mathrm{Ar}$ - autozomno recesivno; $X$ - nasleđivanje preko hromozoma $X$ 
Regardless of type of inheritance, during intraoral clinical examination of patients with $\mathrm{AI}$, anterior open bite is detected in about $50 \%$ of patients. Some authors believe that this clinical picture can be considered as separate syndrome, but up to date by reviewing modern dental literature that kind of approach has not been found.

\section{STRUCTURAL ABNORMALITIES OF ENAMEL - INHERITANCE}

A number of genes have been involved in transcription of matrix proteins and proteinases that control the complex process of crystal growth and their mineralization during enamel formation. Molecular research of genes has found that amelogenesis imperfecta can be caused by mutation of genes that are not directly related to this process [8].

Some scientists have suggested that AI was the first registered anomaly in humans related to the $\mathrm{X}$ chromosome $[10,14]$. Epidemiological studies have confirmed that inheritance of AI through the $\mathrm{X}$ chromosome is present in about $5 \%$ of cases. This form is caused by defects in genes for Amelogenin located on the X chromosome. Clinical picture is more severe in male patients: teeth have very thin layer of enamel with normal color and transparency, or enamel may have normal thickness but be poorly mineralized with loss of transparency and yellow-brown discoloration. Unlike men, women who would inherit mutant gene on the $\mathrm{X}$ chromosome would have vertical grooves in enamel, as the result of the $\mathrm{X}$ chromosome inactivation. Vertical grooves in enamel are important diagnostic sign in females with AI with this type of inheritance. It has been suggested that grooves are formed as the result of both normal and pathological secretion of amelogenin during the amelogenesis.

Autosomal-dominant type of inheritance is more common in US and Europe, while autosomal recessive inheritance is more frequent in the Middle East [15]. It is usually expressed in one or more members of the same generation in one family. Males and females are affected in the same way. It is believed that recessive form of inheritance is more frequent in certain ethnic groups where marriage between family members is common, as well as in ethnic groups where high frequency of mutant genes inheritance exists in some families, such as in some communities in Polynesia [15]. Heterozygote may be phenotypically normal, but carries the disease.

\section{SYNDROMES AND DISEASES ASSOCIATED WITH STRUCTURAL ABNORMALITIES OF ENAMEL}

Modern research has found that structural anomalies of enamel may occur independently or as a part of various syndromes and systemic diseases $[10,16]$. According to the modern dental and medical literature, structural anomalies of enamel have great clinical significance since they are commonly associated with syndromes and systemic diseases, those encountered in everyday dental clinical practice as well as those that belong to the group of rare diseases and syndromes.

Down syndrome is caused by genetic mutation- trisomy or translocation of the chromosome 21. Epidemiological studies have shown that the incidence of Down syndrome in the population is 1:733. Clinical picture is characterized by the following symptoms: mental retardation, macroglossia, muscle hypotonia, obesity, and distinctive appearance [17].

Prader-Willi syndrome is inherited autosomal recessive disease and determined frequency in the population is $1: 25,000$. It is characterized by specific symptomatology such as vision and speech disorders, obesity, hypogonadism, infertility, generalized hypotonia of muscles, mild mental retardation [18].

Tricho-dento-osseous syndrome (TDO) is a rare disease that is autosomal dominant condition. Contemporary medical literature has described only about ten cases of this syndrome. Clinical picture is characteristic: brittle nails, dry and weak hair, sclerosis of long and skull bones, taurodontism and enamel hypoplasia, with hypomaturation and hypoplastic defects $[19,20]$. Abnormalities of nails, hair and bones can be variably expressed, while taurodontism of all permanent molars and enamel defects are always present. Clinical examination shows that except for changes in teeth, these patients do not have other mental or functional disorders, therefore structural anomalies in this syndrome are of great clinical significance. Some authors believe that these are two independent anomalies. Yet, other authors argue that these changes are linked to the mutation in a common DLX3 gene on the chromosome 17.

Taurodontism is autosomal dominant disorder of tooth morphology that is characterized by enlargement of crown and pulp chamber at expense of shorted roots. It occurs as a consequence of absence or delayed invagination of Hertwig's epithelial sheath, which is responsible for the formation of roots. Taurodontism is a disorder which affects usually permanent molars and rarely premolars. It may be atavism, or a new mutation and it is common among primitive peoples and tribes. It can occur in AI, ectodermal dysplasia, TDO, Down and Klinefelter syndrome [21].

Kohlschütter-Tönz syndrome is a progressive degenerative disease, autosomal recessive, and affects central nervous system with manifestation of seizures, motor and mental retardation as well as structural abnormalities of enamel. It manifests in early age, in about 6 months of age [22].

Alström syndrome is a rare autosomal recessive disease, with only 266 cases described in medical literature. Characteristic clinical features include obesity, impaired hearing, impaired function of endocrine glands, heart muscle and vision (corneal dystrophy) [23].

McCune-Albright syndrome is a hereditary ossteodisstrophic pseudohypoparathyroidism. The mechanism of inheritance of this disease is genetic mosaicism. In the clinical picture characteristic white coffee skin pigmentation is present, polyostotic fibrous dysplasia of bones, 
hyperfunction of endocrine glands and premature puberty [24].

Oculodentodigital syndrome (ODD) is an extremely rare autosomal dominant or autosomal recessive disease, which has been documented in medical literature with only 243 cases. Contemporary authors describe the ODD as a form of ectodermal dysplasia. The clinical picture shows syndactyly, microftalmia and mild mental deficits [25].

Morquio syndrome is a rare genetic disease of unknown frequency, it is assumed to be inherited autosomal recessive disease. Metabolic disorder of mucopolysacharides, alteration of bones and internal organs, as well as distinctive appearance of the patient is characteristic for this syndrome [26].

Systemic diseases that affect organs and organ systems in addition to the characteristic clinical picture may be followed by dental problems as a result of mineralization disturbances and adverse effect of the underlying disease on developing tooth germ.

Celiac disease is the most common chronic disease characterized by organism intolerance to gluten, a protein in wheat, barley and rye. The etiology may be autoimmune or genetic. Modern research have reported the incidence of this disease around 1:1,750 in the population [27]. Results of investigations conducted in the population of children and adolescents on deciduous and permanent dentition showed a significantly higher frequency of opalescent hypomineralized zones and structural defects in enamel in the group of children with celiac disease as compared to healthy children $[28,29]$. North American Association for Pediatric Gastroenterology, Hepatology and Nutrition has included specific structural abnormalities of enamel as risk factors for celiac disease [30]. Pedodontists should have a major role in recognition and diagnosis of celiac disease in children.

Cystic fibrosis is an inherited disease, most probably autosomal recessive; the frequency is 1:5,000. In the clinical picture deficiencies in lungs and pancreas, lag in growth, more frequent respiratory infections, diarrhea, and infertility are frequent [31]. Results of the study conducted by Ferrazzano et al. [32], that examined oral and periodontal health in children with cystic fibrosis, have shown the presence of structural anomalies of enamel in the group of affected children. Linkage of cystic fibrosis and structural anomalies of enamel can be explained by metabolic disturbances in organism and long-term drug therapy which may negatively affect tooth germ development.

Con-rod dystrophy represents a group of hereditary non-inflammatory retinal diseases which affect both eyes. It belongs to the group of pigmented retinopathy. Indiscrimination of colors foto-averse, in later stages progressive loss of peripheral vision and night blindness, eventually result in complete loss of vision and disability. This disorder is autosomal recessive. It can be an independent disease or may appear as the part of syndromes such as Bardet Biedl syndrome (a genetic disorder that involves many organs and systems, obesity, impaired speech, vision, mental retardation, hypogonadism, impaired kidney and heart defects), spinocerebral ataxia, metabolic or ectodermal diseases (Amelogenesis imperfecta, juvenile hipotrihosis with macular dystrophy). There is no adequate therapy that would slow down the disease and restore vision; prognosis is poor. The incidence is 1 : 40,000 [33].

Hypophosphatasia is a rare hereditary disorder, autosomal recessive or autosomal dominant, the incidence is 1:100,000. Varying degrees of bone metabolism disorders may be associated with psychiatric disorders [34].

Epidermolysis bullosa is a hereditary disorder that is characterized by gene disorders that regulate the function of collagen and keratin. It is inherited autosomal recessive or dominant, as well as through the $\mathrm{X}$ chromosome. Some cases of autoimmune etiology have been described in the literature. The incidence of disease in population is about 1:50,000. There are characteristic changes of skin and mucous membranes, vesicles and bulla formation after minimal irritation. Patients are usually named "children-butterflies," because of the skin sensitivity [35].

AIDS within its clinical manifestations, according to modern literature, may cause changes in enamel structure. The frequency of dental problems with AIDS varies, but considering the frequency of disease caused by HIV infection and its public, health and socio-economic importance in contemporary society, teeth problems are also getting clinical significance [36].

Albright calcinosis (nephrocalcinosis) belongs to a rare diseases and represents the disturbance in calcium salts transportation through renal parenchyma and their deposition. It is usually asymptomatic, discovered accidentally by ultrasound scan of abdomen. It may be accompanied by chronic urinary tract infections, pyelonephritis, renal colics, polydipsia and polyuria. The appearance of AI and nephrocalcinosis together in a syndrome is extremely rare; only ten cases have been described in the literature. Because of possible association with nephrocalcinosis, the examination of kidneys is recommended in patients with diagnosed hypoplastic AI, of proven autosomal recessive inheritance. Early diagnosis can improve the prognosis of the disease [37].

Platyspondyly is a serious and rare autosomal dominant disease, the result of a new mutation. Abnormalities in the development of skeletal bones, short stature, short hands and feet, undeveloped chest, pelvic bones and planed vertebrae are usually present [38].

Gingival fibromatosis is manifested as fibrous gingival enlargement and can be independent or part of a syndrome when accompanied with hypoplastic AI and delayed tooth eruption. It can be accompanied by slight mental disability in some cases. It is the consequence of endogamy and is inherited as autosomal recessive [39].

Heimler syndrome is a unilateral hearing loss of genetic etiology with characteristic changes on nails, dental dysplasia, mikroftalmia associated with skin defects, cleft lip and palate associated with renal disorders, growth hormone deficiency and other disorders. In contemporary literature there are described cases with enamel abnormalities beside these symptoms.

Avitaminosis A, C and D, infectious diseases (measles, chickenpox, scarlet fever, congenital syphilis), pre- 
term delivery and systemic effects of chemicals are environmental factors that may cause structural abnormalities of enamel. When changes in the formation of enamel are the consequence of external environmental causes, one dentition, a group of teeth or some teeth are only affected [40].

Idiopathic enamel structural abnormalities are of unknown etiology. They occur regardless the inheritance or teratogenic factors. For diagnosis of these cases a detailed medical history and dental examination of other family members is important in order to determine differential diagnosis between AI, tetracycline and fluorosis discoloration. These changes may have one or more causes, can result from autosomal recessive inheritance, or as a consequence of new mutations. They can also be caused by under-expression of dominant genes during inheriting. It has not been certainly confirmed if there is a possibility for transmission of new mutations in the descendants by autosomal dominant type.

Molar incisal hypomineralization is a condition that has been studied a lot in the recent years. The etiology is unknown; it affects one or more first permanent molars and incisors in chronological order in similar, but unrelated sequence. Since there was an evidence of affected offspring, it has been found that in addition to environmental factors, genetic factors also may play a role in the etiology of this disorder [31, 41]. However, further epidemiological and clinical studies with precise methodological criteria are needed to determine the exact impact of certain etiological and predisposing factors on the occurrence of molar incisal hypomineralization.

\section{CONCLUSION}

Enamel abnormalities are a diverse group of disorders. Changes may occur in prenatal period, during enamel formation, and later, during first years of life, sometimes even later during adult life. Factors that cause these disorders are genetic, immunological, teratogenic and sometimes they exist as consequence of systemic disease. A dentist should have a good knowledge of clinical picture, etiology, therapeutic procedures and prognosis of the underlying diseases that have caused enamel disorders. Also, it is necessary to expand basic knowledge of pediatricians regarding the clinical picture of structural anomalies of teeth and their possible association with systemic diseases and syndromes, in order to timely implement all dental preventive, prophylactic and therapeutic measures.

\section{NOTE}

This study was funded by the Ministry of Science and Technological Development of Serbia, the project number 172026.

\section{REFERENCES}

1. Zilberman U, Smith P, Piperno M, Condemi S. Evidence of amelogenesis imperfecta in an early African Homo erectus. J Hum Evol. 2004; 46:647-53.

2. Chosak A, Eidelman E, Wisotski I, Cohen T. Amelogenesis imperfecta among Israeli Jews and the description of a new type of local hypoplastic autosomal recessive amelogenesis imperfecta. Oral Surg Oral Med Oral Pathol. 1979; 47:148-56.

3. Sundell S. Hereditary amelogenesis imperfecta: an epidemiological, genetic and clinical study in a Swedish child population. Swed Dent J. 1986; 31:1-38.

4. Backman B, Holm AK. Amelogenesis imperfecta: prevalence and incidence in a northern Swedish county. Community Dent Oral Epidemiol. 1986; 14:43-7.

5. Džolev A. Amelogenesis imperfecta, epidemiološko, kliničko, terapeutska studija. Novi Sad: Medicinski fakultet Univerziteta u Novom Sadu; 1980.

6. Kavitha B, Priyadharshini V, Sivapathasundharam B, Saraswathi TR. Role of genes in oro-dental diseases. Indian J Dent Res. 2010; 21:270-4.

7. Bloch-Zupan A. When neuropediatrics meets odontology. Neuropediatrics. 2007; 38:57-8.

8. Stephanopoulos G, Garefalaki ME, Lyroudia K. Genes and related proteins involved in amelogenesis imperfecta. J Dent Res. 2005; 84:1117-26.

9. Kim JW, Simmer JP, Lin BP, Seymen F, Bartlett JD, Hu JC. Mutational analysis of candidate genes in 24 amelogenesis imperfecta families. Eur J Oral Sci. 2006; 114:3-12; discussion 39-41, 379.

10. Chaudhary M, Dixit S, Singh A, Kunte S. Amelogenesis imperfecta: report of a case and review of literature. J Oral Maxillofac Pathol. 2009; 13:70-7.

11. Aldred MJ, Savarirayan R, Crawford PJ. Amelogenesis imperfecta: a classification and catalogue for the 21st century. Oral Dis. 2003; 9:19-23.

12. Zlotogora J, Fuks A, Borochowitz Z, Tal Y. Kohlschutter-Tonz syndrome: epilepsy, dementia, and amelogenesis imperfecta. Am J Med Genet. 1993; 46:453-4.

13. Marković D. Stomatološki leksikon. Beograd: Stomatološki fakultet Univerziteta u Beogradu; 2009.

14. Crawford PJ, Aldred MJ. X-linked amelogenesis imperfecta: presentation of two kindreds and a review of the literature. Oral Surg Oral Med Oral Pathol. 1992; 73:449-55.

15. Santos MC, Hart PS, Ramaswami M, Kanno CM, Hart TC, Line SR. Exclusion of known gene for enamel development in two Brazilian families with amelogenesis imperfecta. Head Face Med. 2007; 3:8.

16. Bailleul-Forestier I, Berdal A, Vinckier F, de Ravel T, Fryns JP, Verloes A. The genetic basis of inherited anomalies of the teeth. Part 2: syndromes with significant dental involvement. Eur J Med Genet. 2008; 51:383-408.

17. MacDonald J. Communicating Partners: 30 Years of Building Responsive Relationships with Late-Talking Children including Autism, Asperger's Syndrome (ASD), Down Syndrome, and Typical Developement. London and Philadelphia: Jessica Kingsley Pub; 2004.

18. Wattendorf DJ, Muenke M. Prader-Willi syndrome. Am Fam Physician. 2005; 72:827-30.

19. Seow WK. Trichodentoosseous (TDO) syndrome: case report and literature review. Pediatr Dent. 1993; 15:355-61.

20. Seow WK. Taurodontism of the mandibular first permanent molar distinguishes between the tricho-dento-osseous (TDO) syndrome and amelogenesis imperfecta. Clin Genet. 1993; 43:240-6.

21. Jaspers MT, Witkop CJ Jr. Taurodontism, an isolated trait associated with syndromes and X-chromosomal aneuploidy. Am J Hum Genet. 1980; 32:396-413.

22. Dellow EL, Harley KE, Unwin RJ, Wrong O, Winter GB, Parkins BJ. Amelogenesis imperfecta, nephrocalcinosis, and hypocalciuria syndrome in two siblings from a large family with consanguineous parents. Nephrol Dial Transplant. 1998; 13:3193-6. 
23. Khan TZ, Wagener JS, Bost T, Martinez J, Accurso FJ, Riches DW. Early pulmonary inflammation in infants with cystic fibrosis. Am J Respir Crit Care Med. 1995; 151:1075-82.

24. de Sanctis C, Lala R, Matarazzo P, Andreo M, de Sanctis L. Pubertal development in patients with McCune-Albright syndrome or pseudohypoparathyroidism. J Pediatr Endocrinol Metab. 2003; 16:293-6.

25. Patton MA, Laurence KM. Three new cases of oculodentodigital (ODD) syndrome: development of the facial phenotype. J Med Genet. 1985; 22:386-9.

26. Kitzing B, Allman KC. Scintigraphic features of Morquio's syndrome: a case report. J Med Case Reports. 2011; 5:42.

27. Pastore L, Carroccio A, Compilato D, Panzarella V, Serpico R, Lo Muzio L. Oral manifestations of celiac disease. J Clin Gastroenterol. 2008; 42:224-32.

28. Farmakis E, Puntis JW, Toumba KJ. Enamel defects in children with coeliac disease. Eur J Paediatr Dent. 2005; 6:129-32.

29. Wierink CD, van Diermen DE, Aartman IH, Heymans HS. Dental enamel defects in children with coeliac disease. Int J Paediatr Dent. 2007; 17:163-8.

30. Hill ID, Dirks MH, Liptak GS, Colletti RB, Fasano A, Guandalini S, et al. Guideline for the diagnosis and treatment of celiac disease in children: recommendations of the North American Society for Pediatric Gastroenterology, Hepatology and Nutrition. J Pediatr Gastroenterol Nutr. 2005; 40:1-19.

31. Aren G, Ozdemir D, Firatli S, Uygur C, Sepet E, Firatli E. Evaluation of oral and systemic manifestations in an amelogenesis imperfecta population. J Dent. 2003; 31:585-91.
32. Ferrazzano GF, Orlando S, Sangianantoni G, Cantile T, Ingenito A. Dental and periodontal health status in children affected by cystic fibrosis in a southern Italian region. Eur J Paediatr Dent. 2009; 10:65-8.

33. Bundzman ER, Modesto A. Hypomaturation amelogenesis imperfecta: account of a family with an X-linked inheritance pattern. Braz Dent J. 1999; 10:111-6.

34. Mornet E. Hypophosphatasia. Orphanet J Rare Dis. 2007; 2:40.

35. Coulombe PA, Kerns ML, Fuchs E. Epidermolysis bullosa simplex: a paradigm for disorders of tissue fragility. J Clin Invest. 2009; 119:1784-93.

36. Magalhaes MG, Bueno DF, Serra E, Goncalves R. Oral manifestations of HIV positive children. J Clin Pediatr Dent. 2001; 25:103-6.

37. Hamel CP. Cone rod dystrophies. Orphanet J Rare Dis. 2007; 2:7.

38. Martelli-Junior H, Bonan PR, Dos Santos LA, Santos SM, Cavalcanti $M G$, Coletta RD. Case reports of a new syndrome associating gingival fibromatosis and dental abnormalities in a consanguineous family. J Periodontol. 2008; 79:1287-96.

39. Wygold T, Kurlemann G, Schuierer G. Kohlschutter syndrome an example of a rare progressive neuroectodermal disease. Case report and review of the literature. Clin Padiatr. 1996; 208:271-5.

40. May RL, Goodman AH, Meindl RS. Response of bone and enamel formation to nutritional supplementation and morbidity among malnourished Guatemalan children. Am J Phys Anthropol. 1993; 92:37-51.

41. Crombie F, Manton D, Kilpatrick N. Aetiology of molar-incisor hypomineralization: a critical review. Int J Paediatr Dent. 2009; 19:73-83. 


\title{
Poremećaji strukture gleđi i njihova veza sa sistemskim oboljenjima i sindromima
}

\author{
Marko Jeremić1, Dejan Marković2, Ana Vuković2, Marko Babić3 ${ }^{3}$ Vukoman Jokanović ${ }^{4}$ \\ 'Dom zdravlja, Jagodina, Srbija; \\ ${ }^{2}$ Klinika za dečju i preventivnu stomatologiju, Stomatološki fakultet, Univerzitet u Beogradu, Beograd, Srbija; \\ 3Institut za biologiju i humanu genetiku, Stomatološki fakultet, Univerzitet u Beogradu, Beograd, Srbija; \\ 4Institut za nuklearna istraživanja „Vinča”, Beograd, Srbija
}

\begin{abstract}
KRATAK SADRŽAJ
Etiologija nastanka strukturnih anomalija zuba predmet je mnogih studija, ali još nije potpuno razjašnjena. Nasleđe je dokazani etiološki faktor za mnoge tipove strukturnih anomalija zuba. Faktori koji izazivaju promene u gleđi mogu biti genetske i imunološke prirode, posledica teratogenih faktora i sistemskih bolesti. Genske promene mogu obuhvatati pojedinačne gene, mikrodelecije ili oštećenja samog hromozoma. Veliki broj različitih sistemskih oboljenja koja se dovode u vezu sa strukturnim anomalijama zuba i raznolikost njihove kliničke slike zahteva multidisciplinaran pristup u lečenju. Amelogenesis imperfecta je velika grupa strukturnih anomalija zuba. Može biti samostalno oboljenje ili u sklopu velikog broja sindroma i sistemskih oboljenja. Poznavanje kliničke slike, porekla i patogeneze strukturnih anomalija zuba, te njihove povezanosti s pojedinim sistemskim oboljenjima, od velikog je značaja za svakodnevnu stomatološku praksu s aspekta prevencije, prognostike i terapije. Takođe, potrebno je proširiti osnovno znanje pedijatara u pogledu kliničke slike strukturnih anomalija zuba i njihove moguće veze sa širokim spektrom sistemskih oboljenja i sindroma, kako bi se obezbedio sveobuhvatan klinički tretman. Cilj ovog rada bio je da se predstave etiopatogeneza, klasifikacija i osnovni poremećaji strukture gleđi, odnosno njihova povezanost sa sistematskim oboljenjima i sindromima.
\end{abstract}

Ključne reči: strukturne anomalije zuba; amelogenesis imperfecta; hipoplazija gleđi; nasleđe; sindrom; sistemska oboljenja

\section{UVOD}

Strukturne anomalije gleđi zuba jesu široka grupa poremećaja koji obuhvataju promene u formiranju gleđi nastale delovanjem genetskih ili faktora spoljne sredine. Prvi i najstariji dokaz o postojanju ovih promena datira iz perioda od pre milion i po godina, a predstavlja dečji skelet Homo erectus-a iz Etiopije na čijim se ostacima zuba uočavaju opšta hipoplazija gleđi, smanjena prozirnost i atricija. Najstariji pisani podaci o vertikalno izbrazdanoj gleđi potiču iz 1100. godine i opisuju ostatke zuba severnoameričkog indijanskog deteta [1]. Savremena istraživanja su ustanovila različitu učestalost strukturnih anomalija gleđi zuba ljudi u svetu u zavisnosti od lokaliteta istraživanja. Najmanja učestalost zabeležena je u studiji američkih autora i iznosi 1:14.000 stanovnika [1]. Istraživanje Čosaka (Chosak) i saradnika [2] u Izraelu pokazalo je incidenciju od 1:8.000 stanovnika. Epidemiološka istraživanja urađena u zemljama Zapadne Evrope ukazala su na veću učestalost u poređenju s podacima dobijenim iz američkih studija. Utvrđena incidencija u Švedskoj je 1:4.000 [3], dok je istraživanje koje je obuhvatilo oblast Vesterboten u Švedskoj ukazalo na incidenciju od 1:700 stanovnika [4]. Prema ispitivanjima Džoleva i saradnika [5], učestalost u Srbiji je 1980. godine bila 1:12.582. Potrebna su dalja sveobuhvatna populaciona epidemiološka istraživanja, kako bi se dobili ažurirani podaci o incidenciji i prevalenciji strukturnih anomalija gleđi kod dece i adolescenata na teritoriji Srbije.

Socijalno-ekonomski i klinički značaj amelogenesis imperfecta (AI) i drugih strukturnih anomalija zuba ogleda se u narušavanju kvaliteta života pacijenata i njihovih porodica. Upravo zato precizno poznavanje mogućih etioloških faktora, pravovremeno dijagnostikovanje poremećaja i individualan i multidisciplinaran pristup prilikom primene terapijskih postupaka omogućava sveobuhvatno i adekvatno lečenje bolesnika.
Cilj ovog rada bio je da se predstave etiopatogeneza, klasifikacija i osnovni poremećaji strukture gleđi, odnosno njihova povezanost sa sistemskim oboljenjima i sindromima.

\section{ETIOPATOGENEZA STRUKTURNIH ANOMALIJA GLEĐI}

Razvoj zuba čoveka obuhvata period od stvaranja i migracije ćelija neuralne kreste oko 22. dana embriogeneze do završetka rasta i razvoja korena trećih molara ili umnjaka između 20. i 25. godine. Odontogeneza dovodi do formiranja krunica i korenova svih zuba u vilici. To je složen proces koji prolazi kroz nekoliko faza: formiranje početne zubne gredice, stadijum zametka, stadijum zvona, stadijum kape, formiranje korena i završna diferencijacija odontoblasta i ameloblasta - postmitotičkih ćelija koje stvaraju dentin i gleđ zuba. Savremena istraživanja su pokazala da je odontogeneza pod strogom kontrolom više od 300 gena [6]. Patološke promene na zubima opisane su u okviru kliničke slike mnogih sindroma. Londonska baza genetskih podataka $(L G D)$ opisuje 447 sindroma i bolesti povezanih s anomalijama zuba [7].

Gleđni matriks oblikuju matriksni proteini i proteinaze i transkripcioni faktori koji učestvuju u ekspresiji gena koji kontrolišu sintezu matriksnih proteina i proteinaza. Sinteza proteina gleđnog matriksa, od kojih su najznačajniji enamelin i amelogenin, pod kontrolom je većeg broja gena i enzima od kojih su najvažniji kalikrein i matriks-metalproteinaza 20 (MMP-20) [8]. Patološke promene tokom procesa stvaranja gleđi izazivaju promene u funkciji enzimskih proteina uslovljenih genetskim nedostacima proteina ili enzima proteinaza [9].

Etiologija nastanka strukturnih anomalija zuba predmet je mnogih studija, ali još nije potpuno razjašnjena. Veliki broj raz- 
ličitih kliničkih manifestacija poremećaja strukture gleđi ukazuje na postojanje brojnih etioloških faktora u okviru različitih oboljenja i sindroma koji dovode do promene strukture zubnog tkiva. Savremena istraživanja su pokazala da mnogi tipovi AI nastaju kao posledica genetskih promena, bilo samostalno ili u sklopu različitih sindroma [10].

\section{KLASIFIKACIJA STRUKTURNIH ANOMALIJA GLEĐI}

$\mathrm{Na}$ osnovu rezultata savremenih istraživanja utvrđeno je da su različite kliničke manifestacije strukturnih anomalija gleđi posledica specifičnih anomalija gena koji je u vezi s načinom nasleđivanja [11]. Klasifikacija se vrši na osnovu kliničke slike, tipa nasleđivanja i mutacije specifičnog gena, što se utvrđuje genetskim ispitivanjem obolele osobe i članova najbliže porodice. U literaturi se može naći veliki broj klasifikacija i podela, što se objašnjava heterogenim odlikama samog oboljenja.

AI se često opisuje kao izolovana promena strukture gleđi [12]. Najblaži klinički oblik podrazumeva blagu diskoloraciju krunice zuba. Teški klinički oblik oboljenja je praćen gleđnim tkivom obe denticije koje je slabo mineralizovano ili nedostaje, pri čemu abrazija zuba nastaje ubrzo po njihovom nicanju. U osnovi, poremećaj strukture gleđi može nastati kao posledica nedovoljnog stvaranja gleđi, loše mineralizacije, nepravilnosti u organskom matriksu ili zbog kombinacije svih ovih faktora [13].

Prva podela AI na hipoplastični i hipokalcifikovani tip, koju su predložili Vajnman (Weinmann) i saradnici, datira iz 1945. godine [11]. Vitkopova (Witkop) klasifikacija, koja obuhvata četiri velike grupe, i njena kasnija dopuna na još četrnaest podtipova na osnovu načina nasleđivanja, radiološkog i histološkog izgleda promena, trenutno je najčešće korišćena podela AI (Tabela 1). Gleđna ageneza opisuje se kao poseban redak oblik AI kod kojeg je stvaranje gleđi ozbiljno poremećeno, tako da gleđno tkivo nije formirano.

Bez obzira na tip nasleđivanja, kliničkim intraoralnim pregledom pacijenata sa AI u 50\% slučajeva se uočava prednji otvoren zagrižaj. Pojedini autori smatraju da je ovakva klinička slika zaseban sindrom, ali dosad pregledom savremene stomatološke literature nisu uočene takve klasifikacije.

\section{STRUKTURNE ANOMALIJE GLEĐI - NASLEĐIVANJE}

U stvaranju gleđi učestvuje nekoliko gena koji transkribuju proteine matriksa i proteinaze, koje kontrolišu složeni proces rasta kristala gleđi i njihovu mineralizaciju. Genetskim istraživanjima je utvrđeno da poremećaji u amelogenezi mogu biti uzrokovani i mutacijama na genima koje posredno utiču za ovaj proces [8].

Neki naučnici navode da je AI prva registrovana promena kod čoveka u vezi s hromozomom X [10, 14]. Epidemiološka istraživanja su utvrdila da se nasleđivanje AI preko ovog hromozoma javlja u oko 5\% slučajeva. Ovaj oblik je uzrokovan defektima gena amelogenina na hromozomu X. Kod muških obolelih potomaka klinička slika je težeg oblika: zubi imaju vrlo tanak sloj gleđi normalne boje i prozirnosti ili gleđ normalne debljine, ali loše mineralizovane, sa gubitkom prozirnosti i žuto-braon diskoloracijama. Za razliku od muškaraca, žene koje naslede mutantni gen na X-hromozomu imaju vertikalne brazde u gleđi kao rezultat inaktivacije ovog hromozoma ili lioni- zacije. Vertikalne brazde u gleđi su i važan dijagnostički znak kod ženskih osoba sa AI s ovim tipom nasleđivanja. Smatra se da nastaju kao posledica lučenja normalnog i patološkog amelogenina tokom amelogeneze.

Autozomno dominantni tip nasleđivanja češći je u Sjedinjenim Američkim Državama i Evropi, dok je autozomno recesivno nasleđivanje češće u zemljama Srednjeg istoka [15]. Obično zahvata jednog člana ili više njih u istoj generaciji jedne porodice. Javlja se podjednako i kod muškaraca i kod žena. Smatra se da se recesivan oblik nasleđivanja češće sreće u određenim etničkim grupama gde je stupanje u brak među članovima porodice uobičajena pojava, kao i u etničkim grupama gde postoji visoka učestalost nasleđivanja mutantnog gena u porodici, kao što su neke zajednice u Polineziji [15]. Heterozigoti mogu biti fenotipski normalni, ali nosioci oboljenja.

\section{SINDROMI I BOLESTI KOJI SU U VEZI SA STRUKTURNIM ANOMALIJAMA GLEĐI}

Savremena istraživanja su utvrdila da su strukturne anomalije gleđi poremećaj koji se može javiti izolovano ili u sklopu različitih sindroma i sistemskih oboljenja $[10,16]$. Prema podacima iz savremene stomatološke i medicinske literature, strukturne anomalije gleđi imaju veliki klinički značaj s obzirom na to da su relativno čest pratilac sindroma i sistemskih oboljenja, kako onih koji se mogu sresti u svakodnevnoj stomatološkoj kliničkoj praksi, tako i onih koji se ubrajaju u grupu retkih bolesti i sindroma.

Daunov (Down) sindrom nastaje kao posledica genetskih mutacija - trizomije ili translokacije hromozoma 21. Epidemiološka istraživanja su pokazala da je učestalost ovog sindroma jedan oboleli na 733 stanovnika. Kliničku sliku odlikuju: mentalna zaostalost, makroglosija, hipotonija mišića, gojaznost i karakterističan izgled [17].

Prader-Vilijev (Prader-Willi) sindrom se nasleđuje autozomno recesivno, a njegova učestalost je 1:25.000 stanovnika. Odlikuje se specifičnim simptomima, kao što su: poremećaj vida i govora, gojaznost, hipogonadizam, neplodnost, generalizovana hipotonija mišića i blaga mentalna retardacija [18].

Trihodentoosealni sindrom (TDO) je retko oboljenje koje se nasleđuje autozomno dominantno. U savremenoj medicinskoj literaturi opisano je svega desetak slučajeva navedenog sindroma. Klinička slika je karakteristična: krti nokti, suva i slaba kosa, skleroza dugih i kostiju lobanje, taurodontizam i hipoplazija gleđi s hipomaturacionim i hipokalcifikovanim defektima $[19,20]$. Promene na noktima, kosi i kostima mogu biti različito izražene, dok taurodontizam svih stalnih molara i defekti u gleđi uvek postoje. Kliničkim pregledom se može utvrditi da, izuzev promena na zubima, bolesnici nemaju drugih mentalnih i funkcionalnih poremećaja, pa zato strukturne anomalije u sklopu opisanog sindroma imaju veliki klinički značaj. Pojedini autori smatraju da su u pitanju odvojena stanja. Ipak, neki drugi tvrde da su ove promene u vezi s mutacijom u zajedničkom genu DLX3 na hromozomu 17.

Taurodontizam je autozomno dominantni poremećaj morfoloških osobina zuba koji se odlikuje uvećanjem krunice i komora pulpe na račun smanjenja korenova zahvaćenih zuba. Nastaje kao posledica izostanka ili zakasnele invaginacije Hertvigove (Hertwig) epitelne košuljice, koja je odgovorna za na- 
stanak korena. Taurodontizam je poremećaj koji zahvata stalne molare, ređe premolare. Može biti atavizam ili nova mutacija, češći je među primitivnim narodima i plemenima. Može se javiti kod AI, ektodermalne displazije, TDO, Daunovog i Klinefelterovog (Klinefelter) sindroma [21].

Kolšiter-Tencov (Kohlschütter-Tönz) sindrom je progresivno degenerativno autozomno recesivno oboljenje centralnog nervnog sistema, praćeno epileptičnim napadima, motoričkom i mentalnom retardacijom i strukturnim promenama na gleđi zuba. Ispoljava se u ranom životnom dobu, u uzrastu od oko šest meseci [22].

Alstremov (Alström) sindrom je retko autozomno recesivno oboljenje sa svega 266 slučajeva opisanih u medicinskoj literaturi. Tipična klinička slika obuhvata: gojaznost, poremećaj sluha, funkcije endokrinih žlezda, srčanog mišića i vida (distrofija rožnjače) [23].

Mekjun-Olbrajtov (McCune-Albright) sindrom je nasledni osteodistrofični pseudohipoparatireoidizam. Mehanizam nasleđivanja ovog oboljenja je genski mozaicizam. U okviru kliničke slike javljaju se karakteristične pigmentacije na koži boje bele kafe, policistična fibrozna displazija kostiju, hiperfunkcija endokrinih žlezda i prevremeni pubertet [24].

Okulodentodigitalni sindrom (ODD) je izuzetno retko autozomno dominantno ili autozomno recesivno oboljenje, koje je dosad u medicinskoj literaturi dokumentovano sa svega 243 slučaja. Savremeni autori opisuju ODD kao jedan od oblika ektodermalne displazije. U kliničkoj slici se javljaju sindaktilija mikroftalmija i blagi mentalni poremećaj [25].

Morko (Morquio) sindrom je retka genetska bolest nepoznate učestalosti. Smatra se da se nasleđuje autozomno recesivno. Odlikuju je: poremećaj metabolizma mukopolisaharoidoza, promene na kostima i unutrašnjim organima i karakterističan izgled bolesnika [26].

Sistemska oboljenja koja zahvataju veliki broj organa i organskih sistema, pored tipične kliničke slike, mogu biti praćena i stomatološkim tegobama koje nastaju kao posledica poremećaja mineralizacije i nepovoljnog uticaja osnovnog oboljenja na razvoj klice zuba.

Celijačna bolest je najčešća hronična gastroenterološka bolest koju odlikuje nepodnošljivost organizma na gluten, belančevine pšenice, ječma i raži. Etiologija može biti autoimunska ili nasleđe. Savremena istraživanja pokazuju da je učestalost ovog oboljenja jedan oboleli na 1.750 stanovnika [27]. Rezultati savremenih istraživanja na zubima mlečne i stalne denticije (kod dece i adolescenata) ukazala su na značajno veću učestalost opalescentnih zona hipomineralizacije i strukturnih oštećenja gleđi kod ispitanika sa celijačnom bolešću u poređenju sa zdravom decom $[28,29]$. Severnoameričko udruženje za dečju gastroenterologiju, hepatologiju i ishranu uvrstilo je specifične strukturne anomalije gleđi u faktore rizika za celijačnu bolest [30]. Dečji stomatolozi mogu imati veoma važnu ulogu u prepoznavanju i postavljanju dijagnoze kod dece obolele od ove bolesti.

Cistična fibroza je nasledno oboljenje, smatra se da se prenosi autozomno recesivno, a učestalost je 1:5.000. U kliničkoj slici dominiraju promene na plućima i pankreasu, javlja se zaostajanje u rastu, a česte su i infekcije disajnih organa, dijareja i neplodnost [31]. Rezultati istraživanja Feracana (Ferrazzano) i saradnika [32], koji su ispitivali stanje oralnog i periodontalnog zdravlja dece sa cističnom fibrozom, pokazali su da postoje strukturne anomalije gleđi kod ovih bolesnika. Povezanost cistične fibroze i strukturnih anomalija gleđi može se objasniti metaboličkim poremećajima u organizmu obolelih osoba i dugotrajnom medikamentnom terapijom, koji loše utiču na formiranje zubnog zametka.

Con-rod distrofija je nasledna neinflamatorna grupa poremećaja mrežnjače koja zahvata oba oka. Pripada grupi pigmentnih retinopatija. Javljaju se: nerazlikovanje boja, fotoaverzija, kasnije progresivni gubitak perifernog vida i noćno slepilo. Na kraju dolazi do potpunog gubitka vida i invaliditeta. Nasleđivanje je autozomno recesivno. Može biti samostalna bolest, a može se javiti i u sklopu sindroma, kao što su: Barde-Bidlov (Bardet-Biedl) sindrom (genetski poremećaj koji obuhvata mnoge organe i sisteme, gojaznost, poremećaj govora i vida, mentalnu retardaciju, hipogonadizam, poremećaj bubrega i srčane mane), spinocerebralne ataksije, metaboličke poremećaje ili ektodermalne bolesti (amelogenesis imperfecta, hipotrihoza s juvenilnom makularnom distrofijom). Nema odgovarajuće terapije koja bi usporila bolest i povratila vid, a prognoza je loša. Učestalost ovog poremećaja je 1:40.000 [33].

Hipofosfatazija je redak nasledni poremećaj (autozomno recesivno ili autozomno dominantno nasleđivanje), s učestalošću od 1:100.000. Odlikuje je različit stepen poremećaja metabolizma kostiju, a može biti udružena i sa psihičkim poremećajima [34].

Epidermolysis bullosa je nasledno oboljenje koje se odlikuje poremećajem gena koji reguliše funkciju kolagena i keratina. Nasleđuje se autozomno recesivno ili dominantno, kao i preko $\mathrm{X}$-hromozoma. U literaturi su opisani i slučajevi autoimunske etiologije. Učestalost oboljenja je jedan oboleli na 50.000 stanovnika. Javljaju se tipične promene na koži i sluzokoži, plikovi i bule i posle najmanje iritacije. Oboleli se nazivaju i „deca leptiri” zbog osetljivosti njihove kože [35].

Sida u okviru svojih kliničkih manifestacija, prema podacima iz savremene literature, može izazvati promene u strukturi gleđi. Učestalost dentalnih promena u okviru ovog sindroma varira, ali s obzirom na učestalost oboljenja izazvanog HIV-om i njegov javnozdravstveni i socijalno-ekonomski značaj, u savremenom društvu i promene na zubima dobijaju klinički značaj [36].

Olbrajtova (Albright) kalcinoza (nefrokalcinoza) je retko oboljenje koje se odlikuje poremećajem prenosa kalcijumovih soli kroz parenhim bubrega i njihovim taloženjem. Obično je ne prate simptomi, već se otkriva slučajno ultrazvučnim pregledom trbuha. Može biti praćena i hroničnim urinarnim infekcijama, pijelonefritisom, renalnim kolikama, polidipsijom i poliurijom. Sindrom AI i nefrokalcinoze zajedno je izuzetno redak i u literaturi je opisano svega desetak slučajeva. Moguća veza s nefrokalcinozom preporučuje pregled bubrega kod osoba sa dijagnostikovanom hipoplastičnom AI, dokazanog autozomno recesivnog nasleđivanja. Rana dijagnostika poboljšava prognozu bolesti [37].

Platospondilalija je teško i retko oboljenje koje se prenosi autozomno dominantno ili je posledica nove mutacije. To je poremećaj razvoja koštanog skeleta; bolesnici su niskog rasta, kratkih ruku i nogu, nerazvijenog grudnog koša i kostiju karlice i zaravnjenih kičmenih pršljenova [38].

Gingivalna fibromatoza se manifestuje fibroznim uvećanjem gingive, može se javiti izolovano ili kao deo sindroma, kada je praćena hipoplastičnom AI i zakasnelim nicanjem zuba. U nekim slučajevima praćena je i blagom mentalnom zaostalošću. Posledica je endogamije, a nasleđuje se autozomno recesivno [39]. 
Hajmlerov (Heimler) sindrom predstavlja jednostrani gubitak sluha nasledne etiologije koji se javlja uz tipične promene na noktima, dentinske displazije, mikroftalmije udružene s oštećenjima kože, rascepom usana i nepca, poremećaje funkcije bubrega, nedostatak hormona rasta i druge poremećaje. U savremenoj literaturi su, pored prethodno navedenih simpto$\mathrm{ma}$, opisani i slučajevi s promenama gleđi.

Avitaminoza A, Ci D, infektivna oboljenja (male boginje, ovčje boginje, šarlah, kongenitalni sifilis), prevremen porođaj i sistemsko delovanje hemikalija jesu faktori spoljne sredine koji mogu da utiču na nastanak strukturnih anomalija gleđi. Kod promena u formiranju gleđi nastalih kao posledica uticaja spoljašnje sredine zahvaćena je samo jedna denticija, jedna grupa zuba ili samo pojedini zubi [40].

Idiopatske strukturne anomalije gleđi su nepoznate etiologije. Nastaju nevezano za nasleđe ili neki teratogeni faktor. Prilikom postavljanja dijagnoze u ovim slučajevima odlučujuću ulogu imaju detaljna anamneza i stomatološki pregledi ostalih članova porodice, kako bi se diferencijalnodijagnostički razlikovale AI, tetraciklinska prebojenost i fluoroza. Ove promene mogu imati jedan uzrok ili više njih, a nastaju kao posledica autozomno recesivnog nasleđivanja, odnosno novih mutacija. Javljaju se i kao izraz nedovoljno izraženog dominantnog gena pri nasleđivanju. Nije tačno utvrđeno da li postoji mogućnost prenošenja nove mutacije na potomke po autozomno dominantnom tipu.

Molarno incizalna hipomineralizacija je stanje koje se poslednjih godina dosta proučava. Način njegovog nastanka nije poznat, ali se zna da pogađa jedan prvi stalni molar i sekutić ili više njih u hronološki sličnom, ali nepovezanom, redosle- du. S obzirom na dokaze o zahvaćenim potomcima, utvrđeno je da, osim faktora sredine, i genetski faktori mogu imati ulogu u razvoju ovog poremećaja $[31,41]$. Ipak, potrebna su dalja epidemiološka i klinička istraživanja s preciznim metodološkim kriterijumima, kako bi se utvrdio tačan uticaj pojedinih etioloških i predisponirajućih faktora na nastanak molarno incizalnih hipomineralizacija.

\section{ZAKLJUČAK}

Poremećaji gleđi čine šaroliku i široku grupu poremećaja. Promene mogu nastati u prenatalnom periodu, tokom formiranja gleđi, te kasnije, u prvim godinama života, a nekada i u odraslom dobu. Faktori koji ih izazivaju mogu biti genetske i imunološke prirode, posledica teratogenih faktora i sistemskih bolesti. Bolesti koje ih izazivaju, širina kliničke slike i broj zahvaćenih organa, uključujući i zube, zahtevaju od stomatologa dobro poznavanje kliničke slike, etiologije, terapijskih postupaka i prognoze osnovne bolesti. Takođe, potrebno je proširiti osnovno znanje pedijatara u vezi s kliničkom slikom strukturnih anomalija zuba i njihovom mogućom vezom sa širokim spektrom sistemskih oboljenja i sindroma, kako bi se blagovremeno primenile sve stomatološke preventivne, profilaktičke i terapijske mere.

\section{NAPOMENA}

Ovaj rad je finansiran sredstvima projekta br. 172026 Ministarstva za nauku i tehnološki razvoj Republike Srbije. 